\title{
Aureliu MANEA
}

\section{Grotowski}

Am văzut un spectacol care m-a înfiorat: Prințul constant. Era făcut în aşa fel încât tulburarea psihică să se creeze de la prima apariție a actorilor. Actorii intrau într-un țarc îngust şi rotund cântând, strigând, agitându-se. Erai prins într-un vârtej aproape psihopatic. Erai martorul unui vis coşmaresc. Trupurile actorilor se înlănțuiau şi se despărțeau într-un ritm sufocant care treptat te făcea să crezi că imaginile conțin puteri copleşitoare. Rostirea era muzicală. Fanatismul se desfăşura în modalități estetice abundente. Bogăția imaginației se transforma într-o emoție ce parcă începea să-ți pătrundă în cele mai intime fiorduri ale sufletului. Nimic din spectacol nu era de prisos. Nimic nu devenea rutină. Tot timpul te aflai în miezul actului teatral, ardeau flăcările talentului pretutindeni în sala de spectacol. Am fost atât de uimit, încât mulți ani am meditat la acest fel de artă teatrală. Şi astăzi, după zece ani, păstrez vie imaginea spectacolului. Jerzy Grotowski este un artist singular. Felul său de a face teatru descinde din adâncimi întunecate. Cred că arta sa plină de iluminări ale nopților ține de romantism. Visele sale sunt obscure, conțin multe pasaje ce pot fi supuse psihanalizei.

O interpretare totală a artei sale este imposibilă. Acel spectacol era o rebeliune împotriva simțului comun. Erai supus unui şoc ce voia să-ți trezească spaime ancestrale. Care dintre noi nu e sensibil la tortură? Eroul principal suferea aproape fizic. Ritualul era în aşa fel construit, încât erai violentat tot timpul. Te simțeai prea comod instalat în fotoliul tău de spectator. Deveneai martorul secretelor ascunse zilei. Ceva morbid se infiltra deasupra actelor. Omul devenea când urât, când frumos. Țipetele, şoaptele, cântecele, implorau milă. Era necesară apariția Dreptății. Însă nimeni nu se urnea din loc. Ritualul continua. Te aflai în imposibilitatea de a acționa. Exact ca într-un vis unde nu poți face nimic. lar la sfârşit, epuizat, respirând chinuitor, Prințul constant rămânea întins pe podeaua scenei, a țarcului, iar tu spectator plecai ruşinat în suflet de neputința ta.

Mă gândesc la un vers memorabil: „poezia în fața realului e o bucățică de zahăr aruncată în cuşca tigrului". În țarcul imaginat de scenograful lui Jerzy Grotowski devenea insuportabilă lipsa de milă a omului față de om. Martor al unor rituri crude, sălbatice, chinuitoare, obsedante, tu, spectator aflat în preajma țarcului, erai dispretuit în calitatea ta de spectator. Un impuls adânc se construia în tine, de-a lungul ritului deveneai o problemă, o întrebare. Spuneai: „Ce pot face pentru semenii mei?" erai obligat să iei o atitudine. Fanatismul mesajului spectacolului declara cu febrilitate porunca de a fi Om. Grotowski biciuia comoditatea celui ce zace în istorie, în preajma istoriei. Nimeni nu-l iartă pe cel ce trece nepăsător pe lângă timpul său. Aşa trebuie interpretat şocul grotowskian. Ruşinea ce ți se trezeşte în suflet este obligatorie. Acesta este programul estetic al lui Jerzy Grotowski. Violența spectacolelor sale ține să înfioare în noi acea zonă a nepăsării în fața suferintei. Mă gândeam, în timp ce vedeam spectacolul, la preoții buddhişti de la Saigon care-şi dădeau foc în timpul războiului din Vietnam. Asistând la dezvăluirea țarcului secret, țâşnind din întuneric spre lumină, suferința te copleşea. Ți se cerea milă şi dreptate. Moralitatea incandescentă alimenta actul teatral cu resurse fireşti, dar neîntâlnite prea des. Responsabilitatea devenea o necesitate. Misterul se 


\section{Ryszard CIESLAK în Printul constant}

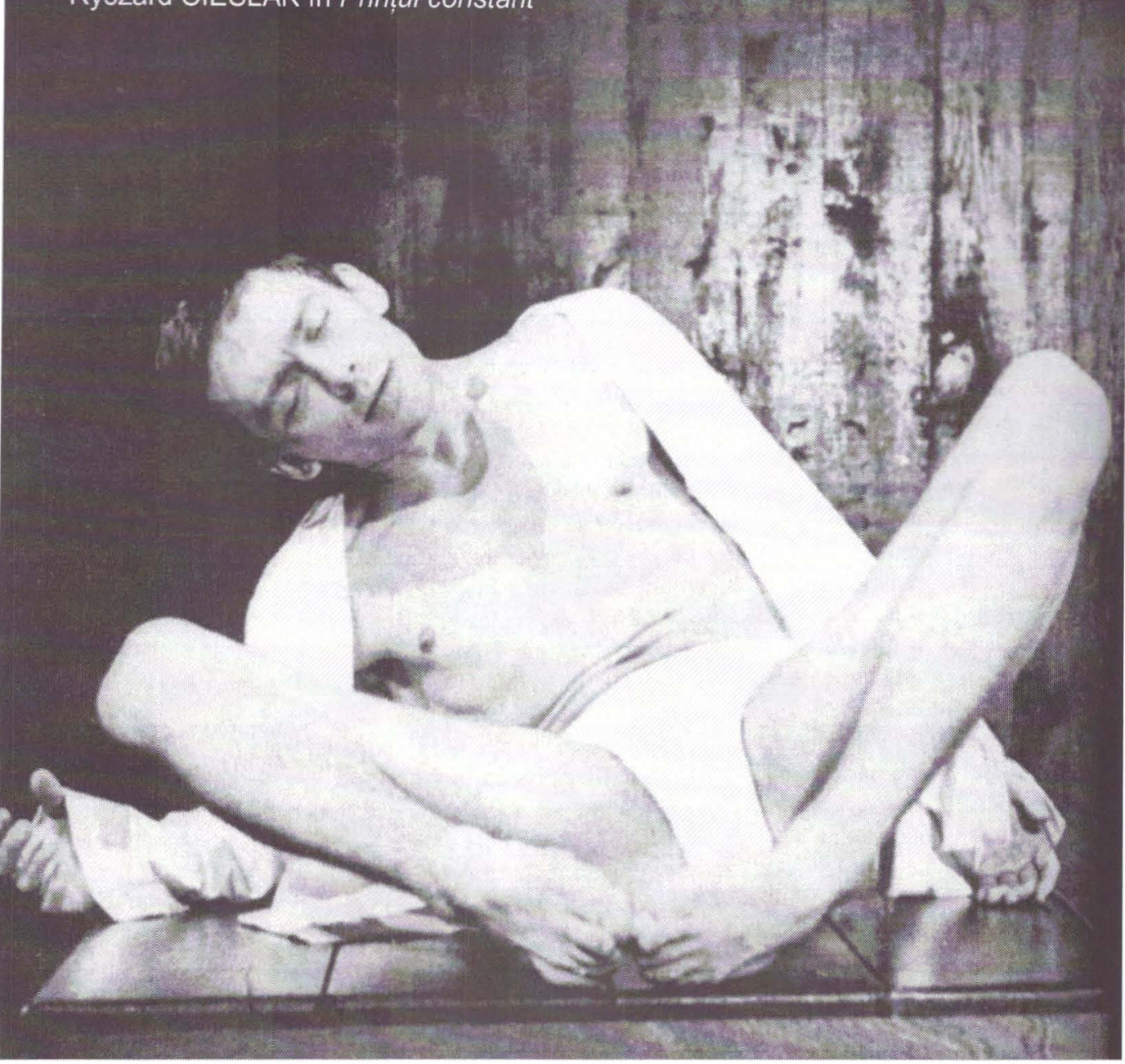

păstra intact. Cei zece spectatori care ne aflam în jurul țarcului, dacă am fi putut, I-am fi luat în brațe pe Prințul Constant şi l-am fi eliberat de agresor. Şi astăzi mă gândesc că, dacă noi, spectatorii, săream în țarc, chiar dacă spectacolul s-ar fi întrerupt, Grotowski ar fi fost pe deplin mulțumit. Aş spune că aceasta este dorința intimă sau secretă a fiecărui regizor. (pp. 58-59)

În Britannicus era prea multă estetică pentru ca stilul de mişcare să aducă naturalismul reactiilor, dar ritualul era foarte influentat de spectacolul Prințul constant al lui Grotowski. Eu consider că prin Rosmersholm am adus în zona de cod teatral din țara noastră influența lui Grotowski. După mine, mulți colegi au folosit acest cod.' (p. 174)

Există doi regizori foarte deosebiți, dar care mă înfioară prin fanatismul lor: Jerzy Grotowski şi Lucian Pintilie. De multe ori mă gândesc la ei şi caut sensul strădaniei lor. (p. 195) 